written, with a more detailed account of the appearances resulting from the paralysis of individual muscles, and the new classification of malignant disease of the pharynx is excellent.

In spite of additions to certain sections the length of the book has been increased by only some 30 pages, owing to judicious pruning in the space devoted to conditions which are less frequently seen at the present time. Most of the illustrations have been seen before, and some belong to the original edition, while a great deal of the text remains unchanged. Much of it bears the stamp of the man who used to stand up at a meeting to say: 'The solution of this problem is quite simple. If you will buy a certain book (price two guineas) you will find written on page etc., etc., etc.' Alas, the price has increased, but the publishers are to be congratulated on maintaining the high standard of the previous editions in spite of shortage of materials.

The wealth of knowledge and experience presented is extraordinary and, for those who wish to pursue the more obscure problems, the bibliography, which has been completely revised, gives an abundance of references. The book is strongly recommended to all interested in the subject.

$$
\text { A.B.-D. }
$$

\section{TEXTBOOK OF GYNAECOLOGY}

By J. H. PeEL, M.A., B.M., B.Ch., F.R.C.S., F.R.C.O.G. 3rd Edition. Pp. xvi +477 , with 2 I 9 illustrations. London: William Heinemann. 1950. $24 \mathrm{~s}$.

This book fulfils all the essentials of a textbook on gynaecology for students and practitioners. It is thoroughly up to date without containing unproven experimental work, yet sufficient mention of recent developments is made to hold the interest. The arrangement is orderly and the subject matter is presented in a very readable fashion.

The drawings and microphotographs, of which there is a thoroughly adequate number, are of high standard and go far in illustrating an already clear text.

R.C.P.

\section{RECENT ADVANCES IN THE PHYSIOLOGY OF VISION}

By Professor Hamilton Hartridge, M.A., M.D., M.R.C.P., Sc.D., F.R.S. Pp. xii +401 , with 236 illustrations. London: J. \& A. Churchill, Ltd. $1950.25 \mathrm{~s}$.

Research into the problems of visual sensation has attracted considerable attention among physiologists in recent times. Since the standard English textbooks were written new approaches along anatomical, physiological and physical lines have developed and have resulted in a reorientation of our attitude to many of these basic problems.

The publishers are to be congratulated upon the acquisition of the Director of the Physiology of
Vision Research Unit to introduce the first volume $\frac{2}{3}$ on the subject in the Recent Advances series. $\mathbb{Q}$ Students of Ophthalmology, as well as physiologists, $c$ will welcome its appearance and will find, in its eight chapters, a comprehensive survey of the newer $\overrightarrow{\vec{\omega}}$ methods of investigation in use, and of the knowledge in which they have resulted. The clarity of the text is considerably enhanced by the inclusion of excellent descriptions of the older work.

H.E.H.

\section{THE FILTERABLE VIRUSES}

By Francis O. Holmes. Pp. xxiii + r6o. London: Ballière, Tindall and Cox. 1948. 20 s.

This book, published as a supplement to Bergey's Manual of Descriptive Bacteriology, puts forward a classification of the filterable viruses together with $\mathcal{N}$ a binomial nomenclature according to Linnaeus. $\omega$ The viruses are treated as members of one order 8 and are sub-divided into three main sub-orders, of namely, bacterial, plant and animal viruses. These $v$ are further sub-divided into families, genera and $\delta$ species.

Two main criticisms can be made against this classification. Firstly, binomial nomenclature is 0 both unwieldy and unnecessary at the present time. Secondly, and this is the main criticism, the classivi fication is based upon symptomatology which is $\mathbb{D}$ assuredly the one basis upon which it should ngt $\vec{\theta}$ be made. It is open to question whether the tinc of has yet come for a classification of the filterabate. viruses to be made; if it has, then the first proble is to decide on what basis that classification should be made. This is a problem for discussion and agreement on an international basis. This book will undoubtedly stimulate action towards that end.

J.A.D.

\section{CLINICAL NUTRITION}

Edited by Norman JolifFe, M.D., Frederick Tisdall, M.D., and Paul R. Cannon, M.D. Pp. xvi +925 , with 78 tables and 127 illustrations, 61 in colour. London: Cassell \& Co., 3 Ltd. I 950 . 90s.

It is now well known that proper nutrition in 3 addition to its role in the prevention of nutritional 0 diseases is not only a major safeguard against all types of illness, but is also one of the most valuable forms of clinical treatment of disease. Until comparatively recently the nutritive values of the N average diets of hospital patients were considerably below their nutritional requirements, but where $N$ the modern treatment of special diets has been prescribed marked improvement in many cases was soon manifest.

The vast literature of nutrition is largely scattered throughout a diversity of technical and medical periodicals which are not readily available to the ${ }^{-}$ general practitioner and it is becoming increasingly ${ }^{2}$ difficult to and the appropriate information at 
times when this may be urgently required. 'Clinical Nutrition' must therefore be welcomed for assembling so much valuable data in a form that makes it available for quick reference. The authors describe the various diets used in clinical work and provide chapters on specific treatments, each of which is written by an expert in his own field. They remind us also that the therapeutic diet should be a modification of the normal diet based on natural foods which are available to the particular patient, allowing for seasonal and environmental variations.

Chapters are also included on dietary and medical history, clinical manifestations of malnutrition, principles of therapy, dietotherapy, treatment of various types of obesity, relation of nutrition to health and its effects upon growth, nutrition in industrial medicine and the effects of low nutrient intake upon efficiency.

The nutritional requirements in health and disease are given and there is an appendix containing a selection of dietary patterns which, allowing for certain present limitations in this country, should be of great assistance. Tables giving the nutritional values of over 250 common foods are presented.

Althogether this is a book of merit and one to be warmly recommended.

R.M.S.

\section{MANSON'S TROPICAL DISEASES}

Edited by Sir Philip H. Manson Bahr, C.M.G., D.S.O., M.A., M.D., D.T.M.\&H., F.R.C.P. 1 3 th Edition. Pp. xiv + I 1 36, with 26 plates and 412 figures. London: Cassell \& Co. $195^{\circ}$. $45 \mathrm{~s}$.

The first edition of ' Manson's Tropical Diseases ' was published 52 years ago and its growth in size from then has been steadily progressive, apart from two rapid increases, the first in 1921 under the first able editorship of Manson's son-in-law, Sir Philip Manson Bahr, and now the $13^{\text {th }}$ edition appears under the same distinguished name. These sudden increases in size reflect the accumulated knowledge gained in the two world wars.

In no branch of medicine has the intensive applied research due to the war yielded such dividends; the 'sulpha' drugs in dysentery, antibiotics such as chloromycetin in typhus and typhoid have revolutionized treatment. The introduction of potent new antimalarial drugs both for cure and prophylaxis, persistent insecticides such as D.D.T. and Gammexane, insect repellents such as dimethyl-phthalate have altered the conditions of life in the tropics. Our greatly increased knowledge of the vitamin deficiencies, a knowledge only gained at the cost of intense human suffering in the jungles of Burma and in P.O.W. camps in the Far East should, if world conditions permit, lead to their final abolition.

The introduction of potent oral drugs such as miracil in schistosomiasis, hetrazan in filariasis and sulphone and its derivatives in leprosy have provide the worker in the tropics with easily administered remedies which can be used on a large scale, both curatively and prophylactically without necessi tating hospitalization of the patient.

The editor is to be congratulated on the successf completion of this herculean task of bringing the edition up to date; this is the best 'Manson $\overline{\text { ' }}$ ever, and by saying that, it is synonymous wit saying that it is the best one volume work on tropica medicine in the world. With such a feast provideक्क one hates to ask for more but a list of new references added between the 12 th and the inevitable 14 th edition would be a boon to the isolated worker im the tropics.

T.C.STC.M.

\section{A SYNOPSIS OF MEDICINE}

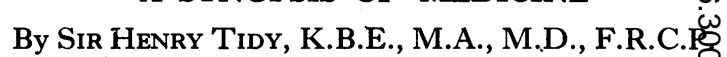
9th Edition. Pp. xx + 1243. Bristol: JohM Wright \& Sons. London: Simpkin Marshaly 1949. 3os.

For the past 30 years Tidy's 'Synopsis of Medicine' has been a sine qua non to countless. students. For the final year, when so much has to be covered, there is no better book of reference? and when examinations have been safely negotiated how many men have packed it up with, perhasp Pye's 'Surgical Handicraft' for their first locigne

In this, its ninth edition, Sir Henry has manares to include a vast amount of new material, but dint of careful revision and pruning has enlarged the text by only four pages. As a sound basis for the student's reference there can be no questio that its I roo pages contain an enormous amount of pithy knowledge, excellently arranged and indexed in most handy form. It is strongly recommendect and will undoubtedly more than uphold the reputation so deservedly gained by its predecessors

\section{A SYNOPSIS OF OBSTETRICS AND GYNAECOLOGY}

By Aleck W. Bourne, M.A., M.B., B.Ch., F.R.C.S్త్రా roth Edition. Pp. vii +530 , with 167 illustra tions. Bristol : John Wright \& Sons, Ltd 1949. 2is.

This very useful and comprehensive book fo요 the non-specialist student has been thoroughly re? vised in the fourth edition. In the preface the author says that he has omitted many out-dated ideas and methods but kept in mind the demands of examiners. Advances in knowledge have been in corporated and, generally speaking, it is thoroughlipe up to date.

On the whole this is an excellent book, both for students and general practitioners. Differences of opinion naturally mean that few will agree wit every statement but differing opinions have been mentioned where possible, and generally a medium way has been advised in treatment. In a book of 